Article

\title{
An Investigation of Potential Sources of Nutraceuticals from the Niger Delta Areas, Nigeria for Attenuating Oxidative Stress
}

\author{
Lucky Legbosi Nwidu 1,2,*(D), Philip Cheriose Nzien Alikwe ${ }^{3}$, Ekramy Elmorsy ${ }^{2,4}$ and \\ Wayne Grant Carter ${ }^{2}$ (1) \\ 1 Department of Experimental Pharmacology and Toxicology, Faculty of Pharmaceutical Sciences, University \\ of Port Harcourt, Port Harcourt PMB 5323, Rivers State, Nigeria \\ 2 School of Medicine, University of Nottingham, Royal Derby Hospital Centre, Derby DE22 3DT, UK; \\ ekramy_elmorsy@yahoo.com (E.E.); wayne.carter@nottingham.ac.uk (W.G.C.) \\ 3 Department of Animal Science, Niger Delta University, Wilberforce Island, Yenegoa PMB 071, Bayelsa State, \\ Nigeria; bushdoctor2013@gmail.com \\ 4 Department of Forensic Medicine and Clinical Toxicology, Faculty of Medicine, Mansoura University, \\ Mansoura 35516, Egypt \\ * Correspondence: menelucky@yahoo.com; Tel.: +234-803341-7432
}

Received: 18 December 2018; Accepted: 15 January 2019; Published: 20 January 2019

\begin{abstract}
Background: Diets rich in fruits, vegetables, and medicinal plants possess antioxidants potentially capable of mitigating cellular oxidative stress. This study investigated the antioxidant, anti-acetylcholinesterase (AChE), and total phenolic and flavonoids contents (TPC/TFC) of dietary sources traditionally used for memory enhancing in Niger Delta, Nigeria. Methods: Dacroydes edulis methanolic seed extract (DEMSE), Cola lepidota methanolic seed extract (CLMSE), Terminalia catappa methanolic seed extract (TeCMSE), Tricosanthes cucumerina methanolic seed extract (TrCMSE), Tetrapleura tetraptera methanolic seed extract (TTMSE), and defatted Moringa oleifera methanolic seed extract (DMOMSE); Dennettia tripetala methanolic fruit extract (DTMFE), Artocarpus communis methanolic fruit extract (ACMFE), Gnetum africana methanolic leaf extract (GAMLE), Musa paradisiaca methanolic stembark extract (MPMSE), and Mangifera indica methanolic stembark extract (MIMSE) were evaluated for free radical scavenging antioxidant ability using 2,2-Diphenyl-1-picrylhydrazyl (DPPH), reducing power capacity (reduction of ferric iron to ferrous iron), AChE inhibitory potential by Ellman assay, and then TPC/TFC contents determined by estimating milli-equivalents of Gallic acid and Quercetin per gram, respectively. Results: The radical scavenging percentages were as follows: MIMSE (58\%), MPMSE (50\%), TrCMSE (42\%), GAMLE $(40 \%)$, CLMSE $(40 \%)$, DMOMSE (38\%), and DEMFE (37\%) relative to $\beta$-tocopherol $(98 \%)$. The highest iron reducing (antioxidant) capacity was by TrCMSE (52\%), MIMSE (40\%) and GAMLE (38\%). Extracts of MIMSE, TrCMSE, DTMFE, TTMSE, and CLMSE exhibited concentration-dependent AChE inhibitory activity $(p<0.05-0.001)$. At a concentration of $200 \mu \mathrm{g} / \mathrm{mL}$, the AChE inhibitory activity and $\mathrm{IC}_{50}(\mu \mathrm{g} / \mathrm{mL})$ exhibited by the most potent extracts were: MIMSE $(\approx 50 \% / 111.9)$, TrCMSE $(\approx 47 \% / 201.2)$, DTMFE $(\approx 32 \% / 529.9)$, TTMSE $(\approx 26 \% / 495.4)$, and CLMSE $(\approx 25 \% / 438.4)$. The highest TPC were from MIMSE (156.2), TrCMSE (132.65), GAMLE (123.26), and CLMSE (119.63) in mg gallic acid equivalents/g, and for TFC were: MISME (87.35), GAMLE (73.26), ACMFE (69.54), CLMSE (68.35), and TCMSE2 (64.34) mg quercetin equivalents/gram. Conclusions: The results suggest that certain inedible and edible foodstuffs, most notably MIMSE, MPMSE, TrCMSE, GAMLE, and CLMSE may be beneficial to ameliorate the potentially damaging effects of redox stress.
\end{abstract}

Keywords: acetylcholinesterase inhibitor; antioxidants; memory enhancers; nutraceuticals 


\section{Introduction}

Oxidative stress is associated with a number of diseases and arises as a consequence of an imbalance between reactive oxygen species (ROS), reactive nitrogen species (RNS), and their dissipation via enzymatic and non-enzymatic mechanisms [1]. Many factors including UV-irradiation, industrial emissions, tobacco smoke, licit or illicit drug usage, heavy metal exposure, inorganic and organic contaminants, and xenobiotics are among the potential exogenous sources of ROS generation in regions such as the Niger Delta, Nigeria. Endogenous sources of ROS include those generated via normal cellular metabolism and via pathological means [2]. The chronic exposure to exogenous factors and/or activation of endogenous means can provoke oxidative insults that may activate stress response pathways including inflammation, cytokine secretion, and apoptosis that might contribute to wide range of pathophysiological events $[1,3]$.

Nutraceuticals are used as dietary supplements, but also as auxiliaries for the perceived prevention and/or treatment of a variety of diseases and disorders. The role of consumption of nutraceuticals and their protective effects in mammals and humans against diseases such as neurodegeneration that includes an elevation of oxidative stress have been reviewed [4,5]. Natural antioxidants in foods may exhibit protective antioxidant effects and thereby aid in the reduction of premature mortality [6,7]. One such group of antioxidants is flavonoids, compounds that are ubiquitous in many edible plants [8]. Collectively, there are an extensive number of low molecular weight organic compounds, including polyphenols and flavonoids that have been termed secondary metabolites or phytochemicals that can be specific to each plant. These arrays of secondary metabolites can exhibit a wide spectrum of pharmacological effects including provision of cellular antioxidant activities capable of scavenging damaging free radicals. This endowed useful activity provides potential functional benefits to humans beyond basic nutrition, and could be exploited as commercial sources of nutraceutical formulations [9]. These potential health benefits provide an impetus for subjecting plant extracts and fractions for scrutiny to elucidate and quantify their respective antioxidant and other health benefiting abilities.

In the Niger Delta region of Nigeria residents may benefit from the wide patronage and chronic consumption of numerous endogenous edible seeds, fruits, nuts, pods, green leafy vegetables, herbs, spices, and crops. These are commonly consumed in either raw or in cooked forms in various cuisines. Many of these foodstuffs have yet to be evaluated for their ability to mitigate oxidative stress. Additionally, there is an association of oxidative stress and a cholinergic deficit with neurodegenerative diseases such as Alzheimer's disease and Parkinson's diseases [10-14]. Hence, the intake of appropriate foodstuffs able to combat this cellular damage and loss of neuronal functionality may limit the development or indeed propagation of neurodegenerative disease [15-18].

Therefore, this study investigated extracts of Dacroydes edulis methanolic seed extract (DEMSE), Cola lepidota methanolic seed extract (CLMSE), Terminalia catappa methanolic seed extract (TeCMSE), Tricosanthes cucumerina methanolic seed extract (TrCMSE), Tetrapleura tetraptera methanolic seed extract (TTMSE), defatted Moringa oleifera methanolic seed extract (DMOMSE); Dennettia tripetala methanolic fruit extract (DTMFE), Artocarpus communis methanolic fruit extract (ACMFE), Gnetum africana methanolic leaf extract (GAMLE), Musa paradisiaca methanolic stembark extract (MPMSE), and Mangifera indica methanolic stembark extract (MIMSE) for in vitro antioxidant and anti-acetylcholinesterase effects and associated polyphenolic and flavonoid contents.

Dacryodes edulis G. Don Lam (Burseraceae) is an edible pear native to the tropics. In the Niger Delta, the fruit is boiled or softened by exposure to heat and used to eat Zea mays (maize) or guinea corn. The pulp may also be boiled or roasted to form a kind of butter $[19,20]$. D. edulis leaf, fruit, and resin extracts have numerous pharmacological activities including antioxidant [21], anti-microbial [22], and anti-carcinogenic [23] properties.

Cola lepidota (Sterculiaceae) is popularly known as monkey cola. The plant is indigenous to tropical Africa and has its center of greatest diversity in West Africa [24]. The native peoples of southern Nigeria and the Cameron relish the fruits as a source of foodstuffs. Seeds of the monkey cola species are not edible, unlike the seeds of kola nut (C. nitida). C. lepidota is used in traditional medicine 
with functions that include its use as a stimulant, and to suppress sleep and for pulmonary problems and cancer-related ailments $[25,26]$, with seed and fruit pulp extracts also displaying antioxidant activity [27]. Phytochemical analysis of the plant included detection of flavonoids [28].

Trichosanthes cucumerina Linn (Cucurbitaceae) is an annual, dioecious climber, widely distributed in Asian countries [29]. T. cucumerina fruit is consumed as a vegetable by rural dwellers, especially in the Western part of Africa. It is commonly called snake gourd, viper gourd, snake tomato, or long tomato [30]. The fruit is used as a cathartic, the seeds used for stomach disorders, anti-febrile and anti-helmintic activities and cardioprotective activities have also been reported [31].

Dennettia tripetala G. Baker (Annonaceae) is a fruit used as a spice and condiment in West Africa [32]. D. tripetala fruit is used in ethnomedicine to treat cold, fever, typhoid, cough, worm infestation, vomiting, stomach upset, and as an appetite enhancer [33]. Strong anti-nociceptive effects comparable to opioid agonists and non-steroidal anti-inflammatory drugs have been demonstrated [33]. Tannins, terpenoids, and other phytochemicals of $D$. tripetala are reported to be responsible for wide range of bioactivities [34].

Artocarpus comminis (Moraceae) is a flowering tree from the mulberry family. It is locally called breadfruit tree because of the "bread-like texture" of its edible fruits. A. comminis grown in the Niger Delta region is extensively used as both a food and traditional medicine. Studies have shown that A. communis possesses several bioactivities, such as antioxidant [35], anti-cancer [36,37], and anti-inflammatory activities $[38,39]$. Biologically active phytochemicals within $A$. communis include flavonoids, chalcones, and stilbenes [40].

Terminalia catappa Linn. (Combretaceae) is native to Southeast Asia. It is widely planted throughout the tropics and the Niger Delta region of Nigeria. T. catappa nut kernel can be eaten raw [41]. The ethnopharmacological properties of this plant have yet to be fully evaluated.

Moringa oleifera (Moringaceae), commonly known as horseradish tree or drumstick tree, is widely cultivated in Africa and other regions including South East Asia, and is considered a multi-purpose plant [42]. There are a broad number of bioactive agents present within the seeds, and for which seed extracts have been reported to exhibit neuroprotective effects [43-45].

Tetrapleura tetraptera (Mimosaceae), locally referred to as "Arindan" in Yoruba, is a flowering plant of the pea family native to West Africa. The dried fruit is used as a seasoning spice in the Southern part of Nigeria $[46,47]$ and in the Niger Delta areas, the pod, fruit, and seeds are used as spices. A neuroprotective effect of $T$. tetraptera has been reported in scopolamine-induced amnesic rats [48].

Gnetum africanum (Gnetaceae) leaf, also known as wild spinach, is utilized as a food [49]. The vegetable is locally known under different nomenclature: sorgo (in Ogoni in Rivers state, Nigeria), afang (Ibibios in South-South, Nigeria), okazi (Igbo in South-East Nigeria), okok or eru (Cameroun), and fumbwa (Democratic Republic of Congo). Leaves are eaten as a vegetable raw or cooked and revered for their nutritional and therapeutic properties. The vegetable is domesticated for its economic potential, and useful component of dietary fibre, essential amino acids, vitamins, and minerals [50].

Musa paradisiaca (Musaceae), a banana plant, has a number of reported medicinal uses, for example banana seed mucilage has been applied as a treatment for catarrh and diarrhea [51]. There is also an extensive list of reported pharmacological activities including hepatoprotective effects [51].

Mangifera indica (Anacardiaceae) aqueous stem bark extract has been utilized as a remedy for diarrhea, fever, gastritis, and ulcers [52]. It has a number of biological activities, including the ability to act as an anti-cancer, and anti-bacterial agent [53].

Collectively, the plants described above were among the commonly edible and non-edible components of daily diets of Niger Deltans, hence an investigation of their relative antioxidant and anti-cholinesterase activities were undertaken. 


\section{Materials and Methods}

\subsection{Collection and Identification of Plant Materials}

The seeds of Dacroydes edulis, Cola lepidota, Tricosanthes cucumerina, Terminalia catappa, Tetrapleura tetraptera, and defatted Moringa oleifera seed; fruits of Dennettia tripetala, Artocarpus communis, green leafy vegetable of Gnetum africana; stembark of Musa paradisiaca and Mangifera indica were collected from Niger Delta University Agricultural Extension farm, Amassoma, Yenegoa, Bayelsa State, Nigeria in March 2015 and authenticated by Mr. Philip Cheriose Nzien Alikwe, an Agriculturalist from the Department of Animal Science, Niger Delta University, Wilberforce Island, Bayelsa State, Nigeria. The voucher numbers (NDUH/P/71-81) were deposited in the University's herbarium, Niger Delta University, Nigeria. All of the samples were shade or air-dried for seven days and powdered using an electrical blender.

\subsection{Preparation of Hydromethanolic Extracts}

The seeds of Dacroydes edulis, Cola lepidota, Tricosanthes cucumerina, Terminalia catappa, Tetrapleura tetraptera, and defatted Moringa oleifera seed; fruits of Dennettia tripetala, Artocarpus communis and leafy vegetable of Gnetum africanum; stembark of Musa paradisiaca and Mangifera indica were powdered, and $10 \mathrm{~g}$ of each were macerated in $100 \mathrm{~mL}$ of $50 \%$ methanol for $72 \mathrm{~h}$ with vigorous hand agitation for one minute three times daily. Double layered gauze was used for filtration to obtain filtrates that were then reduced in volume at $40{ }^{\circ} \mathrm{C}$ on a water bath (Model TT6, Techmel and Techmel, Asaba, Nigeria) to obtain dried extracts. The extracts were weighed and the yield recovered (as a percentage) and recorded (Table 1). Extracts were stored in a refrigerator at $4{ }^{\circ} \mathrm{C}$ in an airtight container until used for experimental studies.

Table 1. Percentage yield, DPPH radical scavenging activity, AChE inhibitory potency, and total phenolic and flavonoid content for the evaluated food sources.

\begin{tabular}{cccccc}
\hline \multirow{2}{*}{$\begin{array}{c}\text { Extracts of } \\
\text { Plants }\end{array}$} & Yield (\%) & $\begin{array}{c}\text { IC }_{\text {50 }} \text { Concentrations }(\mu \mathrm{g} / \mathrm{mL}) \\
\text { DPPH Radical } \\
\text { Scavenging }\end{array}$ & $\begin{array}{c}\text { AChE } \\
\text { Inhibition }\end{array}$ & $\begin{array}{c}\text { Total Phenolic } \\
\text { Content }(\mathbf{m g} \\
\text { GAE/g) }\end{array}$ & $\begin{array}{c}\text { Total Flavonoid } \\
\text { Content (mg } \\
\text { QUER E/g) }\end{array}$ \\
\hline Edible Food & & & & & \\
\hline TeCMSE & 7.1 & 302 & 834.5 & $28.45 \pm 1.40$ & $21.43 \pm 0.98$ \\
\hline TrCMSE & 59.8 & 854 & 201.2 & $132.65 \pm 0.85$ & $64.34 \pm 1.43$ \\
\hline TTMSE & 66.7 & 205 & 967.9 & $25.36 \pm 0.87$ & $17.35 \pm 1.53$ \\
\hline DTMFE & 39.4 & 134 & 654.3 & $75.64 \pm 1.87$ & $41.24 \pm 1.56$ \\
\hline ACMFE & 3.4 & 890 & 576.4 & $102.45 \pm 1.43$ & $69.54 \pm 1.73$ \\
\hline DEMSE & 5.0 & 138 & 529.9 & $95.73 \pm 3.62$ & $53.35 \pm 2.37$ \\
\hline GAMLE & 11.2 & 825 & 321.9 & $123.26 \pm 2.73$ & $73.26 \pm 1.78$ \\
\hline CLMSE & 13.5 & 526 & 438.4 & $119.63 \pm 3.24$ & $68.35 \pm 2.65$ \\
\hline DMOMSE & 21.3 & 145 & 657.1 & $65.15 \pm 1.35$ & $31.43 \pm 0.83$ \\
\hline Non-Edible & & & & & \\
\hline MIMSE & 2.1 & 321 & 111.9 & $156.2 \pm 2.43$ & $87.35 \pm 1.57$ \\
\hline MPMSE & 7.8 & 106 & 619.8 & $85.36 \pm 0.95$ & $42.83 \pm 1.24$ \\
\hline
\end{tabular}

TeCMSE, Terminalia catappa methanolic seed extract; TrCMSE, Tricosanthes cucumerina methanolic seed extract; TTMSE, Tetrapleura tetraptera methanolic seed extract; DTMFE, Dennettia tripetala methanolic fruit extract; ACMFE, Artocarpus communis methanolic fruit extract; DEMSE, Dacroydes edulis methanolic seed extract; GAMLE, Gnetum africanum methanolic leaf extract; CLMSE, Cola lepidota methanolic seed extract; DMOMSE, Defatted Moringa oleifera methanolic seed extract; MIMSE, Mangifera indica methanolic stembark extract; MPMSE, Musa Parasidisiaca methanolic stem-bark extract. GAE: gallic acid equivalents; QUER E: quercetin equivalents. Extract was evaluated at least in triplicate across concentration range, and an approximate $\mathrm{IC}_{50}$ calculated. 


\subsection{Chemicals}

Acetylthiocholine iodide (ATCI), L-ascorbic acid, bovine serum albumin (BSA), 2, 2-Diphenyl-1picrylhydrazyl (DPPH), 5,5-dithiobis [2-nitrobenzoic acid] (DTNB), Folin-Ciocalteu reagent, physostigmine, and $\beta$-tocopherol were all purchased from Sigma Aldrich (Poole, UK), as were all the other chemicals used unless stated otherwise.

\subsection{Animals}

Rat brain homogenates from male F344 strain rats (200-230 g) were utilized as source of mammalian AChE, as described in an earlier report [54]. Rats were maintained at a controlled temperature of $21 \pm 1{ }^{\circ} \mathrm{C}$ and a cycle of $16 \mathrm{~h}$ light $/ 8 \mathrm{~h}$ dark with food intake daily and water ad libitum. Approval for the use of animals was obtained from the University of Nottingham Local Ethical Review Committee (study reference CHE 10, project licence approval code: PPL: 40/2624, approval date 13 June 2005 and the study was executed in line with the Animals Scientific Procedures Act (UK) 1986.

\subsection{2,2-Diphenyl-1-Picrylhydrazyl (DPPH) Radical Scavenging Effect}

Spectrophotometric assays that utilized DPPH radical scavenging were used to quantify antioxidant activity. DPPH has been utilized extensively as a stable organic radical to evaluate scavenging activities of plethora of natural compounds such as flavonoids, polyphenols, and crude plant extracts and fractions. Antioxidants scavenge DPPH radicals by donating an electron to form reduced DPPH changing the colour of the solution from purple to yellow, the level of which can be quantified by spectrophotometry. DPPH radical scavenging assays were performed according to the method of Nwidu et al. [54]. Stock solutions of the plant extracts $(5 \mathrm{mg} / \mathrm{mL})$ were diluted to final concentrations of $200,100,50,25,12.5$, and $6.25 \mu \mathrm{g} / \mathrm{mL}$ in ethanol. Then, $160 \mu \mathrm{L}$ of $0.1 \mathrm{mM} \mathrm{DPPH}$ in ethanol solution was added to $20 \mu \mathrm{L}$ solutions of the extracts as well as a standard and $20 \mu \mathrm{L}$ $\mathrm{H}_{2} \mathrm{O}$. For the standard, $\beta$-tocopherol was prepared at concentrations of $1.56,0.78,0.39,0.195$, and $0.0975 \mathrm{mg} / \mathrm{mL}$. Assays were performed at $37^{\circ} \mathrm{C}$ for $40 \mathrm{~min}$ in the dark, and thereafter the absorbance was read at $517 \mathrm{~nm}$, as described in a previous report [54]. All reactions were performed in triplicates, from which an average was generated.

\subsection{Reducing Power Capacity Assay}

The reducing capacity (antioxidant ability) of the plant extract was also estimated based on its ability to reduce ferric ions $\left(\mathrm{Fe}^{3+)}\right.$ to ferrous ions $\left(\mathrm{Fe}^{2+}\right)$. The plant extracts were assayed over the concentration ranged of $6.25-50 \mu \mathrm{g} / \mathrm{mL}$. Four $\mu \mathrm{L}$ of $5 \mathrm{mg} / \mathrm{mL}$ of each plant extract was mixed with $400 \mu \mathrm{L}$ of phosphate buffer ( $0.2 \mathrm{M}$ dibasic sodium phosphate and $0.2 \mathrm{M}$ monobasic sodium phosphate buffer adjusted to $\mathrm{pH} 7.4), 250 \mu \mathrm{L}$ of $1 \%$ potassium ferricyanide was then added and the mixture incubated at $50{ }^{\circ} \mathrm{C}$ for $20 \mathrm{~min}$. Then, $250 \mu \mathrm{L}$ of $10 \%$ trichloroacetic acid was added, and after mixing, the solution was centrifuged at $3000 \mathrm{rpm}$ for $10 \mathrm{~min}$. One hundred $\mu \mathrm{L}$ from the supernatant was mixed with an equal volume of water, followed by $20 \mu \mathrm{L}$ of freshly prepared ferric chloride solution. After mixing, the absorbance was measured at $700 \mathrm{~nm}$ in a microtiter plate reader, as previously reported [54]. Ascorbic acid was the reference substrate and the following concentration range was employed $(0.3,0.6,0.9,1.2,1.5$, and $3 \mathrm{mg} / \mathrm{mL})$. All reactions were performed in triplicates, from which an average reading was generated.

\subsection{Acetylcholinesterase Inhibition Assay}

The assay for AChE inhibition was based upon the method of Ellman et al. [55], but modified for a 96-well microtiter plate format, as reported in Nwidu et al. [54]. In a microtiter plate, $40 \mu \mathrm{L}$ of plant extract (at concentrations of 200, 20, 2, 0.2 and $0.02 \mu \mathrm{g} / \mathrm{mL}$ ) was mixed with $35 \mu \mathrm{L}$ of $50 \mathrm{mM}$ Tris-HCl (pH 8.0) containing $0.1 \%$ BSA, $50 \mu \mathrm{L}$ of $3 \mathrm{mM} \mathrm{DTNB}$, and $50 \mu \mathrm{L}$ of AChE. The AChE used was either from electric eel at $1 \mathrm{mg} / \mathrm{mL}$ (Sigma, Poole, UK) or that present within rat brain homogenate 
(prepared at 10\% $(w / v)$, according to the procedure of Carter et al. [56,57], which had been diluted 1:10 in $10 \mathrm{mM}$ Tris- $\mathrm{HCl} \mathrm{pH} 8.0$ for assays. Plates were incubated at $37^{\circ} \mathrm{C}$ for $5 \mathrm{~min}$ before the cholinesterase reaction initiated by the addition of $25 \mu \mathrm{L}$ of $15 \mathrm{mM}$ ATCI substrate, resulting in the production of 5-thio-2-nitrobenzoate anion that was read at $412 \mathrm{~nm}$ every $5 \mathrm{~s}$ for $10 \mathrm{~min}$ using a Spectramax microplate reader (Thermo Fisher, Stafford, UK). Eserine was employed at $0.02 \mu \mathrm{g} / \mathrm{mL}$ as a positive control for AChE inhibition. At this concentration (or above), eserine inhibits AChE to $\approx 100 \%$ [55]. All reactions were performed in triplicates, from which an average reading was generated.

\subsection{Determination of Total Phenolic Content}

A Folin-Ciocalteu Reagent (FCR) spectrophotometric method was used to quantify the total phenolic content in plant extracts, as described previously [54]. Twenty $\mu \mathrm{L}$ of each concentration of the plant extracts (ranging from $1-100 \mu \mathrm{g} / \mathrm{mL}$ ) was added to $90 \mu \mathrm{L}$ of water followed by addition of $30 \mu \mathrm{L}$ of FCR, and samples were vigorously shaken within a microtiter plate reader. Within $30 \mathrm{~s}$ and a total assay time of eight minutes, $60 \mu \mathrm{L}$ of $7.5 \% \mathrm{Na}_{2} \mathrm{CO}_{3}$ solution was added to each microtiter well and then plates were incubated at $40^{\circ} \mathrm{C}$ on a shaking incubator. The absorbance of the mixture was read after $40 \mathrm{~min}$ at $760 \mathrm{~nm}$, as detailed in a previous report [56]. Gallic acid was used as the positive control substance. All reactions were performed in triplicates, from which an average reading was generated.

\subsection{Determination of Total Flavonoid Content}

Total flavonoid contents of the plant extracts were determined according to the method described by Nwidu et al. [54] using quercetin as a reference compound. Twenty microliter of plant extracts $(5 \mathrm{mg} / \mathrm{mL})$ were dissolved in ethanol and then mixed with $200 \mu \mathrm{L}$ of $10 \%$ aluminum chloride solution and $1 \mathrm{M}$ potassium acetate solution in microtiter plate wells. Samples were incubated for $30 \mathrm{~min}$ at room temperature, after which the absorbance of the solution was measured at $415 \mathrm{~nm}$, as reported earlier [54]. Quercetin was used as the reference compound. All reactions were performed in triplicates, from which an average reading was generated.

\subsection{Statistical Analysis}

Results are expressed as the mean $\pm \mathrm{SD}$. $\mathrm{IC}_{50}$ values for each extract or fraction were calculated using non-linear regression analysis. A Spearman rank-order correlation coefficient was used to assess the relationship between total phenolic content, total flavonoid content, antioxidant content, and inhibition of AChE activity. Statistical analyses were performed using GraphPad Prism (Version 5.3) for Windows (GraphPad Software, Inc., San Diego, CA, USA, www.graphpad.com). A $p$ value of $<0.05$ for results was considered to be statistically significant.

\section{Results}

\subsection{DPPH Radical Scavenging Activity}

Aqueous methanolic extracts of the inedible stem-bark, edible fruits, seeds and leaf extracts displayed DPPH radical scavenging activities in a concentrations-dependent manner as shown in Figure 1 . From these analyses $\mathrm{IC}_{50}$ values for radical scavenging were calculated with results displayed in Table 1. When assessed at a concentration of $1000 \mu \mathrm{g} / \mathrm{mL}$, the majority of aqueous methanolic extracts displayed significant $(p<0.05-0.001) \mathrm{DPPH}$ radical scavenging effects, that ranged from $\approx 38-58 \%$ of that observed with Vitamin E (set at $100 \%$ ). For the tested extracts, MIMSE (IC $50=$ $321 \mu \mathrm{g} / \mathrm{mL})$ and MPMSE $\left(\mathrm{IC}_{50}=106 \mu \mathrm{g} / \mathrm{mL}\right)$ demonstrated the highest percent inhibitions of $58 \%$ and $50 \%$, respectively, and the latter extract was also the most potent (lowest $\mathrm{IC}_{50}$ value). Collectively, the descending order of DPPH radical scavenging activity was: MIMSE > MPMSE $>$ TrCMSE $>$ GAMLE > CLMSE > DMOMSE > DEMSE > DTMSE > ACMFE > TeCMSE > TTMSE with radical scavenging percentages of 58\%, 50\%, 42\%, 40\%, 40\%, 38\%, 37\%, 21\%, 20\%, 19\%, and 18\%, respectively. The descending orders of potency of the extracts as radical scavengers as determined via $\mathrm{IC}_{50}$ values 
$(\mu \mathrm{g} / \mathrm{mL})$ were: MPMSE $>$ DTMFE $>$ DEMSE $>$ DMOMSE $>$ TTMSE $>$ TeCMSE $>$ MIMSE $>$ CLMSE $>$ GAMLE $>$ TrCMSE $>$ ACMFE (Table 1).
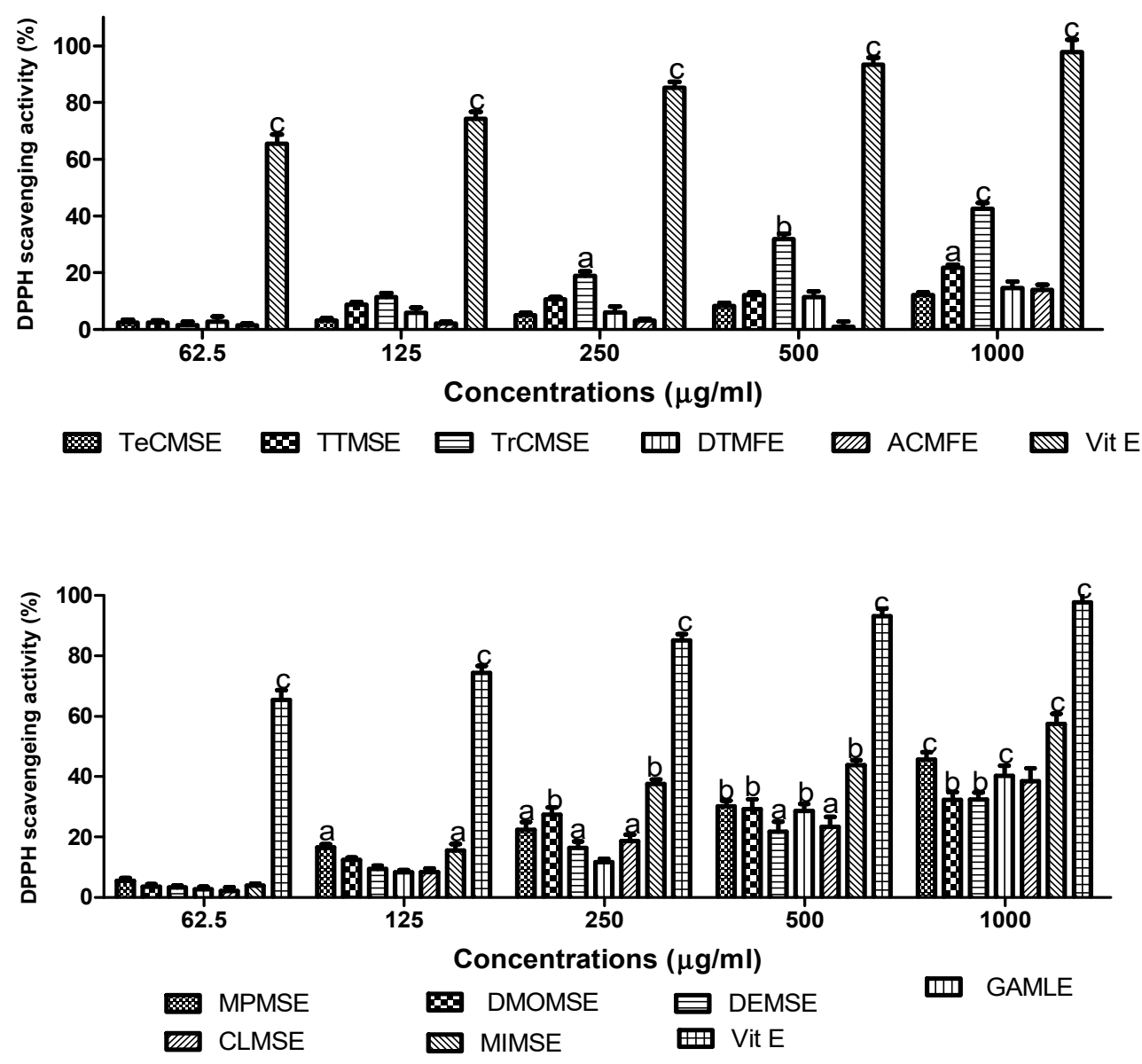

Figure 1. DPPH radical scavenging activity of plant extracts. Plant antioxidant activity was measured via percentage inhibition of radical scavenging of DPPH. Results are expressed as means \pm SEM for three separate experiments at each concentration. TeCMSE, Terminalia catappa methanolic seed extract; TTMSE, Tetrapleura tetraptera methanolic seed extract; TrCMSE, Tricosanthes cucumerina methanolic seed extract; DTMFE, Dennettia tripetala methanolic fruit extract; ACMFE, Artocarpus communis methanolic fruit extract; MPMSE, Musa parasidisiaca methanolic stem-bark extract; DMOMSE, Defatted Moringa oleifera methanolic seed extract; DEMSE, Dacroydes edulis methanolic seed extract; GAMLE, Gnetum africanum methanolic leaf extract; CLMSE, Cola lepidota methanolic seed extract; MIMSE, Mangifera indica methanolic stem-bark extract; Vit E, Vitamin E ( $\beta$-Tocopherol). Results are expressed as means \pm SEM for three separate experiments at each concentration. For marked significance from controls, a: $p<0.05$, b: $p<0.01$, c: $p<0.001$.

\subsection{Reducing (Antioxidant) Capacity}

An evaluation of the reducing capacity of the aqueous methanolic extracts from the edible and non-edible foods showed that these also displayed antioxidant abilities in a concentration-dependent manner (Figure 2). 

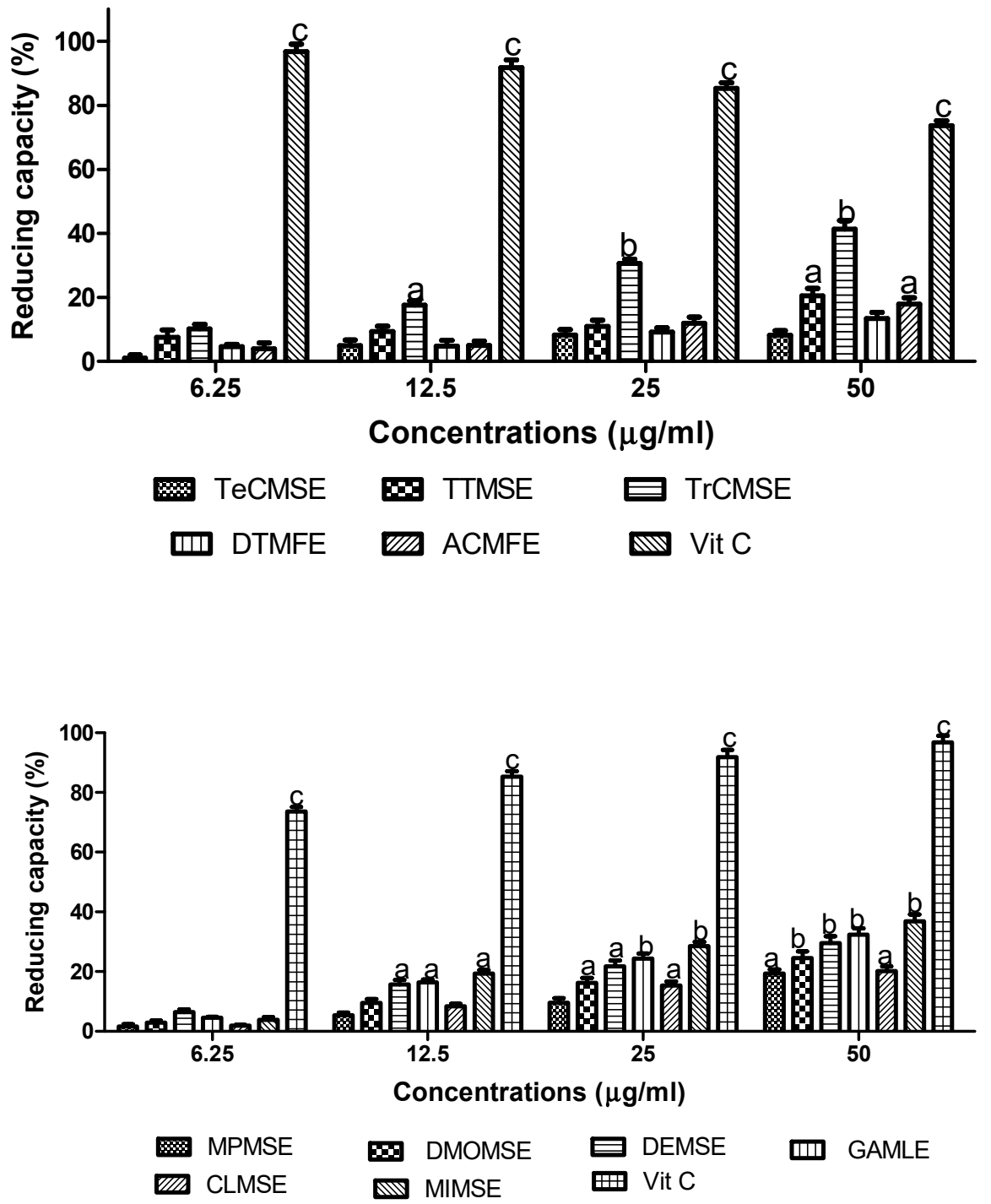

Figure 2. Reducing capacity of plant extracts. Plant reducing power was assessed via the ability to reduce ferric $\left(\mathrm{Fe}^{3+}\right)$ to ferrous $\left(\mathrm{Fe}^{2+}\right)$ iron. The percentage increase of reductive capacity with increasing plant extract concentration was determined. Vitamin C was used as a positive control. Results are expressed as means \pm SEM for three separate experiments at each concentration. TeCMSE, Terminalia catappa methanolic seed extract; TTMSE, Tetrapleura tetraptera methanolic seed extract; TrCMSE, Tricosanthes cucumerina methanolic seed extract; DTMFE, Dennettia tripetala methanolic fruit extract; ACMFE, Artocarpus communis methanolic fruit extract; MPMSE, Musa parasidisiaca methanolic stem-bark extract; DMOMSE, Defatted Moringa oleifera methanolic seed extract; DEMSE, Dacroydes edulis methanolic seed extract; GAMLE, Gnetum africanum methanolic leaf extract; CLMSE, Cola lepidota methanolic seed extract; MIMSE, Mangifera indica methanolic stem-bark extract. Results are expressed as means \pm SEM for three separate experiments at each concentration. For marked significance from controls, a: $p<0.05, \mathrm{~b}: p<0.01, \mathrm{c}: p<0.001$.

At a concentration of $50 \mu \mathrm{g} / \mathrm{mL}$, all of the extracts demonstrated significant antioxidant effects except for TeCMSE and DTMFE when compared with Vitamin C (ascorbic acid). The highest antioxidant capacity was demonstrated by TCMSE2 (52\%), MIMSE $(40 \%)$ and then GAMLE $(38 \%)$ relative to Vitamin $\mathrm{C}$ at $100 \%$. The order of descending reducing capacity for the extracts was: TrCMSE $>$ MIMSE $>$ GAMLE $>$ DEMSE $>$ DMOMSE $>$ ACMFE $>$ CLMSE $>$ MPMSE $>$ DTMFE $>$ TeCMSE 


\subsection{Acetylcholinesterase Inhibitory Activity}

Methanolic aqueous extracts of the inedible stem-bark, edible fruits, seeds, and leaf extracts of the evaluated plants displayed concentrations-dependent AChE inhibition, as shown in Figure 3.
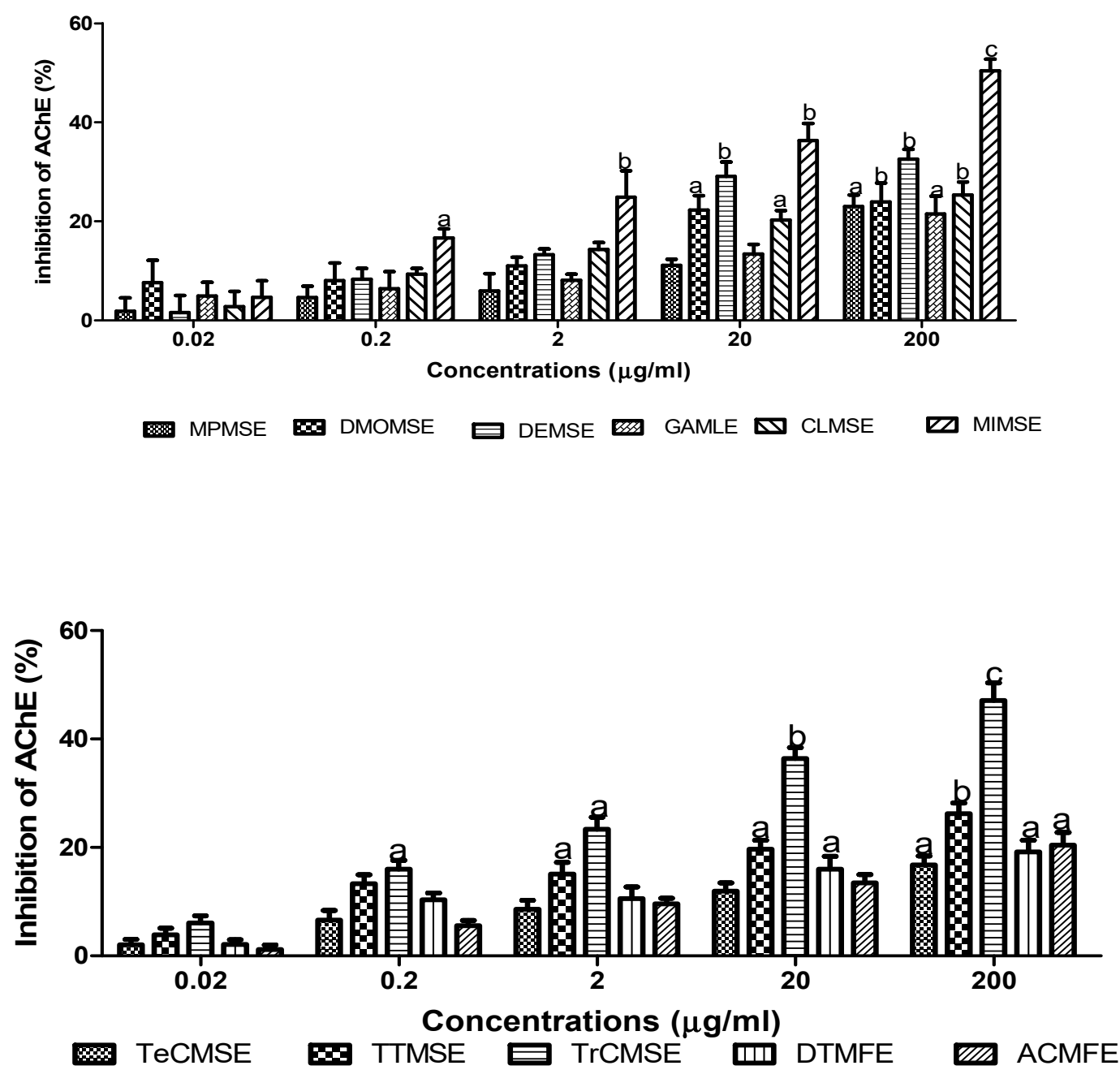

Figure 3. AChE inhibitory activity of plant extracts. Plant inhibition of AChE was measured using a modified Ellman assay, with percentage inhibition of AChE calculated relative to eserine. Results are expressed as means \pm SEM for three separate experiments at each concentration. MPMSE, Musa parasidisiaca methanolic stem-bark extract; DMOMSE, Defatted Moringa oleifera methanolic seed extract; DEMSE, Dacroydes edulis methanolic seed extract; GAMLE, Gnetum africanum methanolic leaf extract; CLMSE, Cola lepidota methanolic seed extract; MIMSE, Mangifera indica methanolic stem-bark extract; TeCMSE, Terminalia catappa methanolic seed extract; TTMSE, Tetrapleura tetraptera methanolic seed extract; TrCMSE, Tricosanthes cucumerina methanolic seed extract; DTMFE, Dennettia tripetala methanolic fruit extract; ACMFE, Artocarpus communis methanolic fruit extract. Results are expressed as means \pm SEM for three separate experiments at each concentration. For marked significance from controls, a: $p<0.05$, b: $p<0.01$, c: $p<0.001$.

Across the investigated concentrations the level of $\mathrm{AChE}$ inhibition was used to generate $\mathrm{IC}_{50}$ concentrations (Table 1).

At the higher concentrations assayed, all evaluated extracts exhibited significant $(p<0.001)$ concentration dependent AChE inhibitory activity, with percentage AChE inhibitions at $200 \mu \mathrm{g} / \mathrm{mL}$ ranging from $\approx 17-50 \%$. The descending order of AChE inhibitory activity for the extracts was MISME $>$ TrCMSE $>$ DEMSE $>$ PPMS $>$ TTMS $>$ CLMSE $>$ DMOMSE $>$ MPMSE $>$ GAMLE $>$ ACMFE $>$ TeCMSE 
The descending order of potency, as determined by $\mathrm{IC}_{50}$ values, were: MIMSE $>$ TrCMSE $>$ GAMLE $>$ CLMSE $>$ DEMSE $>$ ACMFE $>$ MPMSE $>$ DTMSE $>$ DMOMSE $>$ TeCMSE $>$ TTMSE

\subsection{Total Phenolic Content and Total Flavonoid Content}

Total phenolic and total flavonoid contents were determined for each of the extracts and these have been included in Table 1. The relatively higher TPC levels (above $100 \mathrm{mg}$ GAE/g) were observed for MISME, TrCMSE, GAMLE, CLMSE, and ACMFE at 156.2, 132.65, 123.26, 119.63, and $102.45 \mathrm{mg}$ GAE/g, respectively. The relatively higher TFC levels (above $50 \mathrm{mg}$ QUER/g) were recorded with MIMSE, GAMLE, ACMFE, CLMSE, TrCMSE, and DEMSE at 87.35, 73.26, 69.54, 68.35, 64.34, and $53.35 \mathrm{mg}$ QUER/g, respectively.

\subsection{Correlation between AChE Inhibition, Antioxidant Ability, and Total Phenolic and Flavonoid Contents}

To consider if there was a relationship between AChE inhibition potency or DPPH radical scavenging potency and total phenolic or flavonoid content, Spearman rank correlations were calculated. The correlation coefficients ( $R$-values) and significance of association ( $p$-values) are shown in Table 2. The ability of extracts to inhibit $\mathrm{AChE}$ (measured as increasing $\mathrm{IC}_{50}$ values i.e., reduced potency) was significantly inversely correlated with increasing phenolic or increasing flavonoid content. Hence, extracts that displayed relatively high AChE inhibitory activity also retained relatively high phenolic or flavonoid content. By comparison, there was a positive but non-significant correlation between AChE inhibitory potency and either DPPH radical potency, or total phenolic or flavonoid content (Table 2).

Table 2. Correlation variables for $\mathrm{AChE} \mathrm{IC}_{50}$, DPPH radical scavenging $\mathrm{IC}_{50}$ and total phenolic and flavonoid content of the evaluated food sources.

\begin{tabular}{|c|c|c|}
\hline Assessment & AChE Inhibition $\left(\mathrm{IC}_{50}\right)$ & DPPH Radical Scavenging $\left(\mathrm{IC}_{50}\right)$ \\
\hline AChE inhibition $\left(\mathrm{IC}_{50}\right)$ & & $\begin{array}{c}\mathrm{R}=0.243 \\
p=0.42\end{array}$ \\
\hline DPPH Radical scavenging $\left(\mathrm{IC}_{50}\right)$ & $\begin{array}{c}\mathrm{R}=0.243 \\
p=0.42\end{array}$ & \\
\hline Total phenolics & $\begin{aligned} \mathrm{R} & =-0.972 \\
p & =0.0001\end{aligned}$ & $\begin{array}{l}\mathrm{R}=0.488 \\
p=0.127\end{array}$ \\
\hline Total flavonoids & $\begin{array}{l}\mathrm{R}=-0.84 \\
p=0.0012\end{array}$ & $\begin{array}{l}\mathrm{R}=0.392 \\
p=0.232\end{array}$ \\
\hline
\end{tabular}

\section{Discussion}

Medicinal plants, spices, fruits, seeds, or vegetables provide an array of chemical entities with therapeutic potential. For example, medicinal plants may provide antioxidants in the form of flavonoids or polyphenols that are valuable assets for protection against oxidative stress and associated diseases. The public and scientific interest regarding the utilization of natural antioxidants continues to grow due to their potential or indeed perceived health-promoting effects.

Our analyses have shown M. parasidisiaca $(106 \mu \mathrm{g} / \mathrm{mL}), D$. tripetala $(136 \mu \mathrm{g} / \mathrm{mL})$, defatted $M$. oleifera $(138 \mu \mathrm{g} / \mathrm{mL})$, T. tetraptera $(205 \mu \mathrm{g} / \mathrm{mL})$, T. catappa $(302 \mu \mathrm{g} / \mathrm{mL})$ and M. indica $(321 \mu \mathrm{g} / \mathrm{mL})$ have highly active and significant $\mathrm{DPPH}\left(\mathrm{IC}_{50}\right)$ radical scavenging abilities. Other independent studies have also reported antioxidant properties of M. parasidisiaca [58-60], D. tripetala [61] M. oleifera [62,63], T. tetraptera $[64,65]$, T. catappa [66], M. indica $[67,68]$, and T. cucumenina $[69,70]$. Additionally, the protective effect of a natural extract from the stem-bark of $M$. indica was able to counter age-associated oxidative stress in elderly humans, indicative of its potential to act as a nutraceutical in vivo [68]. The antioxidant effects of the fruit of Artrocarpus communis [71] and the leaves of Dacroydes edulis [72] have also been reported. Interestingly, fruit (Dacroydes edulis) and vegetable (Gnetum africanum) intake 
and an imbalance of oxidant/antioxidant status was reported to be associated with the development of diabetic retinopathy [72], with a recommendation that a diet rich in antioxidant supplements and tight glycemic control could postpone the onset of diabetic retinopathy [72].

The assessment of diets in a number of epidemiological studies and via quantitative evaluation have suggested that adherence to a Mediterranean-style diet and diets rich in fruits and vegetables may have protective benefits against age-related cognitive decline and neurodegenerative diseases [73-82]. This led us to consider the acetylcholinesterase inhibitory activity of these plants, since cholinesterase inhibitors are the mainstay of treatment for mild to moderate AD. An assessment of the potencies of a broad number of plant anticholinesterases inhibitors has been undertaken [83,84], with $\mathrm{IC}_{50}$ values ranging from 0.3 to $100.4 \mu \mathrm{g} / \mathrm{mL}$. Hence, the plant extracts analyzed herein only displayed mild or moderate anti-AChE activities, with $M$. indica the most potent $\left(\mathrm{IC}_{50}\right.$ of $\left.111.9 \mu \mathrm{g} / \mathrm{mL}\right)$. Nevertheless, although only relatively weak cholinesterase inhibitors per se, chronic consumption of these foodstuffs might still provide provision of chemical entities able to ameliorate development or propagation of neurodegenerative disease. Indeed, an aqueous decoction of mango (Mangifera indica L.) stem bark has been developed on an industrial scale to be used as a nutritional supplement, cosmetic, and as a nutraceutical with neuroprotective effects $[68,85,86]$. Furthermore, neuroprotective effects of Moringa oleifera seed extract [52,53] and likewise T. tetraptera have also been demonstrated [48].

Our study also quantified the levels of phenolics and flavonoids, as these phytochemicals are widely distributed in the plant kingdom and possess antioxidant and anti-inflammatory activities [87]. Many of the active extracts investigated possessed high polyphenols and flavonoids content (Table 1) comparable to gallic acid and quercetin, respectively. Certain dietary phytochemicals, such as polyphenols have been reported to possess potential protection of cognitive function during aging [88] and may serve as natural neuroprotective agents [89-91]. In addition to their action as neuroprotective agents, flavonoids may also be efficacious candidates as potential pharmaceuticals or nutraceuticals for the treatment of AD [92]. Antioxidant activities of green tea phytochemicals and nutraceuticals such as curcumin, catechins, licopene, resveratrol, piperine, and anthocyanins, have been reported using in vitro and in vivo models [93,94].

Of interest, there was a significant inverse correlation between the potency of AChE inhibition ( $\mathrm{IC}_{50}$ values) and total phenolic or flavonoid contents. This suggests that the agent(s) responsible for the AChE inhibitory activity are resident within the phenolic and flavonoid compounds. By contrast, there was no significant correlation between the AChE inhibition potency and that for DPPH radical scavenging, suggesting that the agent(s) that provide AChE inhibition is different from that for radical scavenging. Likewise, there was no correlation between $\mathrm{AChE}$ inhibitory potency and antioxidant activity, or between antioxidant activity and TPC or TFC, hence the chemical agent(s) that provided antioxidant protection were not AChE inhibitors, or likely to be abundant polyphenols or flavonoids.

A clear limitation of our study is that we have only assessed in vitro properties of these plant parts and their respective polyphenol and flavonoid content. We are unable to directly comment on how much of these foodstuffs are typically eaten, and indeed this will vary extensively between peoples and their food preparation methods. However, irrespective of these limitations, it is provocative to propose that a suitable diet rich in certain phytochemicals may provide beneficial counter-measures against oxidative stress-induced damage and its impact upon disease pathogenesis and propagation.

Author Contributions: L.L.N. was involved with conception and design of the study, performed experiments, collection and assemblage of the data, drafting of the article and final approval of the article, provided administrative, technical and logistic support. P.C.N.A. provided the plant materials used for this investigation. E.E. performed experiments, analyzed and interpreted the data, and provided statistical expertise. W.G.C. participated in critical editing and revision of the article for important intellectual content; provision of laboratory space and funding.

Funding: This research received no external funding.

Acknowledgments: The authors are grateful to the University of Nottingham for the International Visiting Fellowship grants awarded to W.G.C. to support L.L.N. and E.E. 
Conflicts of Interest: The authors confirm that there are no conflicts of interest connected with the publication of this manuscript. The funding sponsor had no role in the design of this study; in the collection, analyses, or interpretation of data; in the writing of the manuscript; or in the decision to publish the results in this journal.

\section{References}

1. Chen, Q.; Wang, Q.; Zhu, J.; Xiao, Q.; Zhang, L. Reactive oxygen species: Key regulators in vascular health and diseases. Br. J. Pharmacol. 2018, 175, 1279-1292. [CrossRef]

2. Birben, E.; Sahiner, U.M.; Sackesen, C.; Erzurum, S.; Kalayci, O. Oxidative stress and antioxidant defenses. World Allergy Organ. J. 2012, 5, 9-19. [CrossRef] [PubMed]

3. Espinosa-Diez, C.; Miguel, V.; Mennerich, D.; Kietzmann, T.; Sánchez-Pérez, P.; Cadenas, S.; Lamas, S. Antioxidant responses and cellular adjustments to oxidative stress. Redox Biol. 2015, 6, 183-197. [CrossRef] [PubMed]

4. Dadhania, V.P.; Trivedi, P.P.; Vikram, A.; Tripathi, D.N. Nutraceuticals against Neurodegeneration: A Mechanistic Insight. Curr. Neuropharmacol. 2016, 14, 627-640. [CrossRef] [PubMed]

5. Sadhukhan, P.; Saha, S.; Dutta, S.; Mahalanobish, S.; Sil, P.C. Nutraceuticals: An emerging therapeutic approach against the pathogenesis of Alzheimer's disease. Pharmacol. Res. 2018, 129, 100-114. [CrossRef]

6. Gupta, R.K.; Patel, A.K.; Shah, N.; Chaudhary, A.K.; Jha, U.K.; Yadav, U.C.; Gupta, P.K.; Pakuwal, U. Oxidative stress and antioxidants in disease and cancer: A review. Asian Pac. J Cancer Prev. 2014, 15, 4405-4409. [CrossRef] [PubMed]

7. Lobo, V.; Patil, A.; Phatak, A.; Chandra, N. Free radicals, antioxidants and functional foods: Impact on human health. Pharmacogn. Rev. 2010, 4, 118-126. [CrossRef] [PubMed]

8. Perez-Vizcaino, F.; Fraga, C.G. Research trends in flavonoids and health. Arch. Biochem. Biophys. 2018, 646, 107-112. [CrossRef]

9. Krzyzanowska, J.; Czubacka, A.; Oleszek, W. Dietary phytochemicals and human. Adv. Exp. Med. Biol. 2010, 698, 74-98.

10. Pratico, D.; Clark, C.M.; Liun, F.; Rokach, J.; Lee, V.Y.; Trojanowski, J.Q. Increase of brain oxidative stress in mild cognitive impairment: A possible predictor of Alzheimer disease. Arch. Neurol. 2002, 59, 972-976. [CrossRef]

11. Barnham, K.J.; Masters, C.L.; Bush, A.I. Neurodegenerative diseases and oxidative stress. Nat. Rev. Drug Discov. 2004, 3, 205-214. [CrossRef] [PubMed]

12. Keller, J.N.; Schmitt, F.A.; Scheff, S.W.; Ding, Q.; Chen, Q.; Butterfield, D.A.; Markesbery, W.R. Evidence of increased oxidative damage in subjects with mild cognitive impairment. Neurology 2005, 64, 1152-1156. [CrossRef] [PubMed]

13. Guidi, I.; Galimberti, D.; Lonati, S.; Novembrino, C.; Bamonti, F.; Tiriticco, M.; Fenoglio, C.; Venturelli, E.; Baron, P.; Bresolin, N.; et al. Oxidative imbalance in patients with mild cognitive impairment and Alzheimer's disease. Neurobiol. Aging 2006, 27, 262-269. [CrossRef] [PubMed]

14. Butterfield, D.A.; Boyd-Kimball, D. Oxidative Stress, Amyloid- $\beta$ Peptide, and Altered Key Molecular Pathways in the Pathogenesis and Progression of Alzheimer's Disease. J. Alzheimer Dis. 2018, 62, 1345-1367. [CrossRef] [PubMed]

15. Da Costa, L.A.; Badawi, A.; El-Sohemy, A. Nutrigenetics and modulation of oxidative stress. Ann. Nutr. Metab. 2012, 60, 27-36. [CrossRef] [PubMed]

16. Thapa, A.; Carroll, N.J. Dietary Modulation of Oxidative Stress in Alzheimer's Disease. Int. J. Mol. Sci. 2017, 18, 1583. [CrossRef]

17. Ravi, S.K.; Narasingappa, R.B.; Vincent, B. Neuro-nutrients as anti-Alzheimer's disease agents: A critical review. Crit. Rev. Food Sci. Nutr. 2018, 30, 1-20. [CrossRef] [PubMed]

18. Lopes da Silva, S.; Vellas, B.; Elemans, S.; Luchsinger, J.; Kamphuis, P.; Yaffe, K.; Sijben, J.; Groenendijk, M.; Stijnen, T. Plasma nutrient status of patients with Alzheimer's disease: Systematic review and meta-analysis. Alzheimer Dement. 2014, 10, 485-502. [CrossRef]

19. Irvine, F.R. Woody Plants of Ghana with Special Reference to Their Uses; Oxford University Press: London, UK, 1961.

20. Leakay, R.R.B. Potential for Novel food products from Agroforestry Trees. A review. Food Chem. 1999, 66, 1-4. [CrossRef] 
21. Erukainure, O.L.; Mopuri, R.; Oyebode, O.A.; Koorbanally, N.A.; Islam, M.S. Dacryodes edulis enhances antioxidant activities, suppresses DNA fragmentation in oxidative pancreatic and hepatic injuries; and inhibits carbohydrate digestive enzymes linked to type 2 diabetes. Biomed. Pharmacother. 2017, 96, 37-47. [CrossRef]

22. Tee, L.H.; Yang, B.; Nagendra, K.P.; Ramanan, R.N.; Sun, J.; Chan, E.S.; Tey, B.T.; Azlan, A.; Ismail, A.; Lau, C.Y.; et al. Nutritional compositions and bioactivities of Dacryodes species: A review. Food Chem. 2014, 165, 247-255. [CrossRef] [PubMed]

23. Atawodi, S.E. Nigerian foodstuffs with prostate cancer chemopreventive polyphenols. Infect. Agent Cancer 2011, 6, S9. [CrossRef] [PubMed]

24. Rusell, T.A. The cola of Nigeria and Cameroon. Trop. Agric. 1955, 32, 210-240.

25. Engel, N.; Opermann, C.; Falodun, A.; Udo, K. Proliferative effects of five traditional Nigerian medicinal plant extracts on human breast and bone cancer cell lines. J. Ethnopharmacol. 2011, 137, 1003-1010. [CrossRef]

26. Oghenerobo, V.I.; Falodun, A. Antioxidant activities of the leaf extract and fractions of Cola lepidota, K. Schum (Sterculiaceae). Niger. J. Biotechnol. 2013, 25, 31-36.

27. Essien, E.E.; Peter, N.S.; Akpan, S.M. Chemical Composition and Antioxidant Property of Two Species of Monkey Kola (Cola rostrata and Cola lepidota, K. Schum) Extracts. Eur. J. Med. Plants 2015, 7, 31-37. [CrossRef]

28. Ene-Obong, H.N.; Okudu, H.O.; Asumugha, U.V. Nutrient and phytochemical composition of two varieties of Monkey kola (Cola parchycarpa and Cola lepidota): An under utilised fruit. Food Chem. 2016, 193, 154-159. [CrossRef]

29. Jayaweera, D.M.A. Medicinal Plants (Indigenous and Exotic) Used in Ceylon Part 2; National Science Council of Sri Lanka: Colombo, Sri Lanka, 1980; pp. 162-163.

30. Sandhya, S.; Vinod, K.; Chandra, S.; Aradhana, R.; Vamshi, S. An Updated Review on Trichosanthes cucumerina, L. Int. J. Pharm. Sci. Rev. Res. 2010, 1, 56-58.

31. Shah, S.L.; Mali, V.R.; Zambare, G.N.; Bodhankar, S.L. Cardioprotective activity of methanol extract of fruit of Trichosanthes cucumerina on doxorubicin-induced cardiotoxicity in Wistar rats. Toxicol. Int. 2012, 19, 167-172. [CrossRef]

32. Adjalian, E.; Sessou, P.; Fifa, TD.; Dangou, B.J.; Odjo, T.; Figueredo, G.; Noudogbessi, J.P.; Kossou, D.; Menut, C.; Sohounhloue, D. Chemical composition and bioefficacy of Dennettia tripetala and Uvariodendron angustifolium leaves essential oils against the angoumois grain moth, Sitotroga cerealella. Int. J. Biosci. 2014, 5 , 161-172.

33. Oyemitan, I.A.; Iwalewa, E.O.; Akanmu, M.A.; Olugbade, T.A. Antinociceptive and anti-inflammatory effects of essential oil of Dennettia tripetala, G. Baker in rodents. Afr. J. Tradit. Complement. 2008, 5, 355-362. [CrossRef]

34. Lewis, K.; Ausubel, F.M. Prospects for plant-derived anti-bacterial. Nat. Biotechnol. 2006, 24, $1504-1507$. [CrossRef] [PubMed]

35. Lee, C.W.; Ko, H.H.; Lin, C.C.; Chai, C.Y.; Chen, W.T.; Yen, F.L. Effect of Artocarpus communis Extract on UVB Irradiation-Induced Oxidative Stress and Inflammation in Hairless Mice. Int. J. Mol. Sci. 2013, 14, 3860-3873. [CrossRef] [PubMed]

36. Arung, E.T.; Wicaksono, B.D.; Handoko, Y.A.; Kusuma, I.W.; Shizu, K.; Yulia, D.; Sandra, F. Cytotoxic effect of artocarpin on T47D cells. J. Nat. Med. 2010, 64, 423-429. [CrossRef]

37. Tzeng, C.W.; Tzeng, W.S.; Lin, L.T.; Lee, C.W.; Yen, F.L.; Lin, C.C. Artocarpus communis induces Autophagic Instead of Apoptotic Cell Death in Human Hepatocellular Carcinoma Cells. Phytomedicine 2015, 23, 528-540. [CrossRef]

38. Lin, J.A.; Fang, S.C.; Wu, C.H.; Huang, S.M.; Yen, G.C. Anti-inflammatory effect of the 5,7,4'-trihydroxy-6geranylflavanone isolated from the fruit of Artocarpus communis in S100B-induced human monocytes. J. Agric. Food Chem. 2011, 59, 105-111. [CrossRef] [PubMed]

39. Hsu, C.L.; Chang, F.R.; Tseng, P.Y.; Chen, Y.F.; El-Shazly, M.; Du, Y.C.; Fang, S.C. Geranyl flavonoid derivatives from the fresh leaves of Artocarpus communis and their anti-inflammatory activity. Planta Med. 2012, 78, 995-1001. [CrossRef]

40. Han, A.R.; Kang, YJ.; Windono, T.; Lee, S.K.; Seo, E.K. Prenylated flavonoids from the heartwood of Artocarpus communis with inhibitory activity on lipopolysaccharide-induced nitric oxide production. J. Nat. Prod. 2006, 69, 719-721. [CrossRef] 
41. Anand, A.V.; Divya, N.; Kotti, P.P. An updated review of Terminalia catappa. Pharmacog. Rev. 2015, 9, 93-98. [CrossRef]

42. Singhal, A.K.; Naithani, V.; Bangar, O.P. Medicinal Plants with a Potential to Treat Alzheimer and Associated Symptoms. Intern. J. Nutr. Pharmacol. Neurol. Dis. 2012, 2, 84-91. [CrossRef]

43. Galuppo, M.; Giacoppo, S.; Iori, R.; De Nicola, G.R.; Milardi, D.; Bramanti, P.; Mazzon, E. 4( $\alpha$-L-rhamnosyloxy)-benzyl isothiocyanate, a bioactive phytochemical that defends cerebral tissue and prevents severe damage induced by focal ischemia/reperfusion. J. Biol. Regul. Homeost. Agents 2015, 29, 343-356. [PubMed]

44. Jaafaru, M.S.; Nordin, N.; Shaari, K.; Rosli, R.; Abdull Razis, A.F. Isothiocyanate from Moringa oleifera seeds mitigates hydrogen peroxide-induced cytotoxicity and preserved morphological features of human neuronal cells. PLoS ONE 2018, 13, e0196403. [CrossRef] [PubMed]

45. Mensah, J.K.; Ikhajiagbe, B.; Edema, N.E.; Emokhor, J. Phytochemical, nutritional and antibacterial properties of dried leaf powder of Moringa oleifera (Lam.) from Edo Central Province Nigeria. J. Nat. Prod. Plant Resour. 2012, 2, 107-112.

46. Essien, E.U.; Izunwane, B.C.; Aremu, C.Y.; Eka, O.U. Significance for humans of the nutrient contents of the dry fruit of Tetrapleura tetraptera. Food Hum. Nutr. 1994, 45, 47-51. [CrossRef]

47. Aladesanmi, J.A. Tetrapleura tetraptera: Molluscicidal activity and chemical constituents. Afr. J. Tradit. Complement. Altern. Med. 2007, 4, 23-26. [CrossRef]

48. Odubanjo, V.O.; Ibukun, E.O.; Oboh, G.; Adefegha, S.A. Aqueous extracts of two tropical ethnobotanicals (Tetrapleura tetraptera and Quassia undulata) improved spatial and non-spatial working memories in scopolamine-induced amnesic rats: Influence of neuronal cholinergic and antioxidant systems. Biomed. Pharmacother. 2018, 99, 198-204. [CrossRef] [PubMed]

49. Ali, F.; Assanta, M.A.; Robert, C. Gnetum africanum: A wild food plant from the African forest with many nutritional and medicinal properties. J. Med. Food 2011, 14, 1289-1297. [CrossRef]

50. Alozie, Y.E.; Ene-Obong, H.N. Recipe standardization, nutrient composition and sensory evaluation of waterleaf (Talinum triangulare) and wild spinach (Gnetum africanum) soup "afang" commonly consumed in South-south Nigeria. Food Chem. 2018, 238, 65-72. [CrossRef]

51. Lavanya, K.; Abi Beaulah, G.; Vani, G. Musa Parasidisiaca-A review of phytochemistry and pharmacology. World J. Pharm. Med. Res. 2016, 2, 163-173.

52. Masibo, M.; He, Q. Mango Bioactive Compounds and Related Nutraceutical Properties-A Review. Food Rev. Int. 2009, 25, 346-370. [CrossRef]

53. Lauricella, M.; Emanuele, S.; Calvaruso, G.; Giuliano, M.; D'Anneo, A. Multifaceted Health Benefits of Mangifera indica, L. (Mango): The Inestimable Value of Orchards Recently Planted in Sicilian Rural Areas. Nutrients 2017, 9, 525. [CrossRef]

54. Nwidu, L.L.; Elmorsy, E.; Thornton, J.; Wijamunige, B.; Wijesekara, A.; Tarbox, R.; Warren, A.; Carter, W.G. Anti-acetylcholinesterase activity and antioxidant properties of extracts and fractions of Carpolobia lutea. Pharm. Biol. 2017, 55, 1875-1883. [CrossRef] [PubMed]

55. Ellman, G.L.; Courtney, K.D.; Andres, V.; Featherstone, R.M. A new and rapid colorimetric determination of acetylcholinesterase activity. Biochem. Pharmacol. 1961, 7, 88-95. [CrossRef]

56. Carter, W.G.; Tarhoni, M.; Rathbone, A.J.; Ray, D.E. Differential protein adduction by seven organophosphorus pesticides in both brain and thymus. Hum. Exp. Toxicol. 2007, 26, 347-353. [CrossRef] [PubMed]

57. Carter, W.G.; Tarhoni, M.H.; Ray, D.E. Analytical approaches to investigate protein-pesticide adducts. J. Chromatogr. B 2010, 878, 1312-1319. [CrossRef] [PubMed]

58. Vijayakumar, S.; Presannakumar, G.; Vijayalakshmi, N.R. Antioxidant activity of banana flavonoids. Fitoterapia 2008, 79, 279-282. [CrossRef] [PubMed]

59. Loganayaki, N.; Rajendrakumaran, D.; Manian, S. Antioxidant capacity and phenolic content of different solvent extracts from banana (Musa paradisiaca) and mustai (Rivea hypocrateriformis). Food Sci. Biotechnol. 2010, 19, 1251-1258. [CrossRef]

60. Panigrahi, P.N.; Dey, S.; Sahoo, M.; Dan, A. Antiurolithiatic and antioxidant efficacy of Musa paradisiaca pseudostem on ethylene glycol-induced nephrolithiasis in rat. Indian J. Pharmacol. 2017, 49, 77-83. [PubMed] 
61. Okoh, S.O.; Iweriegbor, B.C.; Okoh, O.O.; Nwodo, U.U.I.; Okoh, A. Bactericidal and antioxidant properties of essential oils from the fruits Dennettia tripetala G. Baker. BMC Complement. Altern. Med. 2016, 16, 486. [CrossRef]

62. Randriamboavonjy, J.I.; Rio, M.; Pacaud, P.; Loirand, G.; Tesse, A. Moringa oleifera Seeds Attenuate Vascular Oxidative and Nitrosative Stresses in Spontaneously Hypertensive Rats. Oxid. Med. Cell Longev. 2017, 2017, 4129459. [CrossRef]

63. Lamou, B.; Taiwe, G.S.; Hamadou, A.; Abene; Houlray, J.; Atour, M.M.; Tan, P.V. Antioxidant and Antifatigue Properties of the Aqueous Extract of Moringa oleifera in Rats Subjected to Forced Swimming Endurance Test. Oxid. Med. Cell Longev. 2016, 2016, 3517824. [CrossRef] [PubMed]

64. Moukette, B.M.; Pieme, A.C.; Biapa, P.C.; Njimou, J.R.; Stoller, M.; Bravi, M.; Yonkeu, N.J. In Vitro Ion Chelating, Antioxidative Mechanism of Extracts from Fruits and Barks of Tetrapleura tetraptera and Their Protective Effects against Fenton Mediated Toxicity of Metal Ions on Liver Homogenates. Evid. Based Complement. Altern. Med. 2015, 2015, 423689. [CrossRef] [PubMed]

65. Ene-Obong, H.; Onuoha, N.; Aburime, L.; Mbah, O. Chemical composition and antioxidant activities of some indigenous spices consumed in Nigeria. Food Chem. 2018, 238, 58-64. [CrossRef] [PubMed]

66. Pandya, N.B.; Tigari, P.; Dupadahalli, K.; Kamurthy, H.; Nadendla, R.R. Antitumor and antioxidant status of Terminalia catappa against Ehrlich ascites carcinoma in Swiss albino mice. Indian J. Pharmacol. 2013, 45, 464-469.

67. Núñez-Sellés, A.J.; Vélez Castro, H.T.; Agüero-Agüero, J.; González-González, J.; Naddeo, F.; De Simone, F.; Rastrelli, L. Isolation and quantitative analysis of phenolic antioxidants, free sugars, and polyols from mango (Mangifera indica L.) stem bark aqueous decoction used in Cuba as a nutritional supplement. J. Agric. Food Chem. 2002, 50, 762-766. [CrossRef]

68. Pardo-Andreu, G.L.; Philip, S.J.; Riaño, A.; Sánchez, C.; Viada, C.; Núñez-Sellés, A.J.; Delgado, R. Mangifera indica, L. (Vimang) Protection against Serum Oxidative Stress in Elderly Humans. Arch Med. Res. 2006, 37, 158-164. [CrossRef] [PubMed]

69. Arawwawala, M.; Thabrew, I.; Arambewela, L. In vitro and in vivo evaluation of antioxidant activity of Trichosanthes cucumerina aerial parts. Acta Biol. Hung. 2011, 62, 235-243. [CrossRef] [PubMed]

70. Bamidele, O.P.; Fasogbon, M.B. Chemical and antioxidant properties of snake tomato (Trichosanthes cucumerina) juice and Pineapple (Ananas comosus) juice blends and their changes during storage. Food Chem. 2017, 220, 184-189. [CrossRef]

71. Lee, C.W.; Ko, H.H.; Lin, C.C.; Chai, C.Y.; Chen, W.T.; Yen, F.L. Artocarpin attenuates ultraviolet B-induced skin damage in hairless mice by antioxidant and anti-inflammatory effect. Food Chem. Toxicol. 2013, 60, 123-129. [CrossRef]

72. Moise, M.M.; Benjamin, L.M.; Etienne, M.; Thierry, G.; Ndembe Dalida, K.; Doris, T.M.; Samy, W.M. Intake of Gnetum africanum and Dacryodes edulis, imbalance of oxidant/antioxidant status and prevalence of diabetic retinopathy in central Africans. PLoS ONE 2012, 7, e49411. [CrossRef]

73. Martinez-Lapiscina, E.H.; Clavero, P.; Toledo, E.; Estruch, R.; Salas-Salvado, J.; San Julian, B.; Sanchez-Tainta, A.; Ros, E.; Valls-Pedret, C.; Martinez-Gonzalez, M.Á. Mediterranean diet improves cognition: The PREDIMED-NAVARRA randomised trial. J. Neurol. Neurosurg. Psychiatry 2013, 84, 1318-1325. [CrossRef] [PubMed]

74. Jin, Y.; Oh, K.; Oh, S.I.; Baek, H.; Kim, S.H.; Park, Y. Dietary intake of fruits and beta-carotene is negatively associated with amyotrophic lateral sclerosis risk in Koreans: A case-control study. Nutr. Neurosci. 2014, 17, 104-108. [CrossRef]

75. Hardman, R.J.; Kennedy, G.; Macpherson, H.; Scholey, A.B.; Pipingas, A. Adherence to a Mediterranean-style diet and effects on cognition in adults: A qualitative evaluation and systematic review of longitudinal and prospective trials. Front. Nutr. 2016, 3, 22. [CrossRef] [PubMed]

76. Dai, Q.; Borenstein, A.R.; Wu, Y.; Jackson, J.C.; Larson, E.B. Fruit and vegetable juices and Alzheimer's disease: The Kame Project. Am. J. Med. 2006, 119, 751-759. [CrossRef] [PubMed]

77. Fischer, K.; Melo van Lent, D.; Wolfsgruber, S.; Weinhold, L.; Kleineidam, L.; Bickel, H.; Scherer, M.; Eisele, M.; van den Bussche, H.; Wiese, B.; et al. Prospective Associations between Single Foods, Alzheimer's Dementia and Memory Decline in the Elderly. Nutrients 2018, 10, 852. [CrossRef] [PubMed] 
78. Arnim, C.A.; Herbolsheimer, F.; Nikolaus, T.; Peter, R.; Biesalski, H.K.; Ludolph, A.C.; Riepe, M.; Nagel, G.; ActiFE Ulm Study Group. Dietary antioxidants and dementia in a population-based case-control study among older people in South Germany. J. Alzheimer Dis. 2012, 31, 717-724. [CrossRef]

79. Dardiotis, E.; Kosmidis, M.H.; Yannakoulia, M.; Hadjigeorgiou, G.M.; Scarmeas, N. The Hellenic Longitudinal Investigation of Aging and Diet (HELIAD): Rationale, study design, and cohort description. Neuroepidemiology 2014, 43, 9-14. [CrossRef]

80. De Rest, O.; Wang, Y.; Barnes, L.L.; Tangney, C.; Bennett, D.A.; Morris, M.C. APOE $\varepsilon 4$ and the associations of seafood and long-chain omega-3 fatty acids with cognitive decline. Neurology 2016, 86, 2063-2070. [CrossRef]

81. Loughrey, D.G.; Lavecchia, S.; Brennan, S.; Lawlor, B.A.; Kelly, M.E. The Impact of the Mediterranean Diet on the Cognitive Functioning of Healthy Older Adults: A Systematic Review and Meta-Analysis. Adv. Nutr. Bethesda 2017, 8, 571-586.

82. Gardener, H.; Caunca, M.R. Mediterranean Diet in Preventing Neurodegenerative Diseases. Curr. Nutr. Rep. 2018, 7, 10-20. [CrossRef]

83. Murray, A.P.; Faraoni, M.B.; Castro, M.J.; Alza, N.P.; Cavallaro, V. Natural AChE inhibitors from plants and their contribution to Alzheimer's disease therapy. Curr. Neuropharmacol. 2013, 11, 388-413. [CrossRef] [PubMed]

84. Dos Santos, T.C.; Gomes, T.M.; Pinto, B.A.S.; Camara, A.L.; Paes, A.M.A. Naturally occurring anticholinesterases inhibitors and their potential use for Alzheimer's disease therapy. Front. Pharmacol. 2018, 9, 1192. [CrossRef]

85. Kawpoomhae, K.; Sukma, M.; Ngawhirunpat, T.; Opanasopit, P.; Sripattanaporn, A. Antioxidant and neuroprotective effects of standardized extracts of Mangifera indica leaf. J. Pharm. Sci. 2010, 34, 32-43.

86. Infante-Garcia, C.; Ramos-Rodriguez, J.J.; Delgado-Olmos, I.; Gamero-Carrasco, C.; Fernandez-Ponce, M.T.; Casas, L.; Mantell, C.; Garcia-Alloza, M. Long-Term Mangiferin Extract Treatment Improves Central Pathology and Cognitive Deficits in APP/PS1 Mice. Mol. Neurobiol. 2017, 54, 4696-4704. [CrossRef] [PubMed]

87. Biesalski, H.K. Polyphenols and inflammation: Basic interactions. Curr. Opin. Clin. Nutr. Metab. Care 2007, 10, 724-728. [CrossRef]

88. Thangthaeng, N.; Poulose, S.M.; Miller, M.G.; Shukitt-Hale, B. Preserving brain function in aging: The anti-glycative potential of berry fruit. Neuromol. Med. 2016, 18, 465-473. [CrossRef]

89. Ataie, A.; Shadifar, M.; Ataee, R. Polyphenolic antioxidants and neuronal regeneration. Basic Clin. Neurosci. 2016, 7, 81-90. [CrossRef]

90. Almeida, S.; Alves, M.G.; Sousa, M.; Oliveira, P.F.; Silva, B.M. Are Polyphenols Strong Dietary Agents Against Neurotoxicity and Neurodegeneration? Neurotox. Res. 2016, 30, 345-366. [CrossRef]

91. Ruan, Q.; Ruan, J.; Zhang, W.; Qian, F.; Yu, Z. Targeting NAD ${ }^{+}$degradation: The therapeutic potential of flavonoids for Alzheimer's disease and cognitive frailty. Pharmacol. Res. 2018, 128, 345-358. [CrossRef]

92. Darvesh, A.S.; Carroll, R.T.; Bishayee, A.; Geldenhuys, W.J.; Van der Schyf, C.J. Oxidative stress and Alzheimer's disease: Dietary polyphenols as potential therapeutic agents. Expert Rev. Neurother. 2010, 10, 729-745. [CrossRef]

93. Arab, H.; Mahjoub, S.; Hajian-Tilaki, K.; Moghadasi, M. The effect of green tea consumption on oxidative stress markers and cognitive function in patients with Alzheimer's disease: A prospective intervention study. Caspian J. Int. Med. 2016, 7, 188-194.

94. Rice-Evans, C.; Miller, N.; Paganga, G. Antioxidant properties of phenolic compounds. Trends Plant Sci. 1997, 2, 152-159. [CrossRef]

(C) 2019 by the authors. Licensee MDPI, Basel, Switzerland. This article is an open access article distributed under the terms and conditions of the Creative Commons Attribution (CC BY) license (http:/ / creativecommons.org/licenses/by/4.0/). 